\title{
Use of nanofiltration membranes for the desalting of peptide fractions from whey protein enzymatic hydrolysates
}

\author{
Marie Christiana Wijers, Yves Pouliot*, Sylvie F. Gauthier, \\ Michel Pouliot, Lyson Nadeau
}

\begin{abstract}
Département de sciences des aliments et de nutrition, Centre de recherche Stela, université Laval, Sainte-Foy, G1K7PA, PQ, Canada
\end{abstract}

(Received 15 April 1998; accepted 11 August 1998)

\begin{abstract}
The performance of nanofiltration membranes for the desalting of a peptide mixture from tryptic hydrolysate of whey proteins containing $0.5 \mathrm{~mol} \cdot \mathrm{L}^{-1}$ sodium chloride has been investigated. Membranes are consisting of a strongly negatively charged material (MW15, MG17, BQ01, B006, B007) or of a polyamide (MX07) layered onto a polysulfone support. A satisfactory desalting of the whey protein tryptic hydrolysate has been obtained with all membranes under study both for dead-end and cross-flow filtration. The most suitable membrane for desalination was MX07, providing the highest permeability for salt and the lowest loss of peptidic material. For all membranes, RP-HPLC analysis of the permeates obtained in dead-end filtration revealed the presence of 6 different peptidic sequences from $\beta$-lactoglobulin $(\beta-\lg )$, but in a low amount $(<11 \%)$. The peptides found in the permeates are characterized by a net charge of 0 or +1 , while other peptides of similar molecular weight but containing negatively charged amino acid residues (Glu, Asp) remain in the retentates. Furthermore, it has been demonstrated that, compared to dead-end filtration, cross-flow filtration results in higher ion-peptide selectivities and less membrane fouling. (c) Inra/Elsevier, Paris.
\end{abstract}

nanofiltration / peptide / desalting / membrane selectivity / module configuration

Résumé - Utilisation de membranes de nanofiltration pour le dessalage de fractions peptidiques obtenues par hydrolyse enzymatique des protéines de lactosérum. Les performances de membranes de nanofiltration ont été étudiées pour le dessalage d'un hydrolysat trypsique de protéines de lactosérum contenant $0,5 \mathrm{~mol} \cdot \mathrm{L}^{-1}$ de $\mathrm{NaCl}$. Les membranes à l'étude étaient constituées de matériel fortement chargé négativement (MW15, MG17, BQ01, B006, B007) ou de polyamide (MX07) laminé sur un support de polysulfone. Un dessalage satisfaisant de l'hydrolysat enzymatique a été obtenu avec toutes les membranes, tant par filtration frontale que tangentielle. Toutefois, l'efficacité de la membrane MX07 s'est demarquée par un passage maximal du sel et une perte minimale du matériel peptidique. Une analyse chromatographique (RP-HPLC) des perméats obtenus par filtration frontale a

*Correspondence and reprints. E-mail: yves.pouliot@aln.ulaval.ca 
permis de confirmer la présence de 6 peptides différents, issus de la $\beta$-lactoglobuline ( $\beta$-lg), mais en très faible quantité $(<11 \%$ ). Ces peptides possèdent en commun une charge nette de $0 \mathrm{ou}+1$, alors que d'autres peptides de poids moléculaire moyen équivalent, mais contenant des résidus acides (Glu, Asp), n'ont pas été retrouvés dans les perméats. En comparant la filtration frontale et la filtration tangentielle, il apparaît que la filtration tangentielle présente une sélectivité ion-peptide plus élevée et un colmatage membranaire plus faible. (C) Inra/Elsevier, Paris.

nanofiltration / peptide / dessalage / sélectivité membranaire/ configuration modulaire

\section{INTRODUCTION}

Worldwide there is an increasing interest in the application of whey proteins and their enzymatic hydrolysates as functional and nutritional ingredients in food, pharmaceutical and cosmetic industries [15]. These products increase in value if they have been demineralized [11]. A conventional industrial process for whey demineralization is to concentrate the whey by evaporation (EV), followed by demineralization of the concentrated whey using electrodialysis (ED) and/or ion-exchange (IE) [20]. Nanofiltration (NF) is also a promising alternative for the concentration and demineralization of acid and sweet whey $[8,9,11,12$, 20]. NF membranes have a high permeability for monovalent salts $(\mathrm{NaCl}, \mathrm{KCl})$ and have a very low permeability for organic compounds (lactose, proteins, urea) [16, 20]. An advantage of NF compared to EV and ED is the simultaneous concentration and demineralization of whey. This leads to a considerable reduction of costs for energy consumption, waste water disposal and total processing costs $[8,11,20]$.

Besides demineralization, pressure driven membrane processes, such as nanofiltration (NF) and ultrafiltration (UF) can be applied to fractionate proteins, peptides and amino acids in whey products. Turgeon and Gauthier [19] fractionated peptides in enzymatically hydrolyzed whey protein concentrate. A two step ultrafiltration (UF) process was used in which the first UF membrane had a molecular weight cut-off (MWCO) of
$30000 \mathrm{~g} \cdot \mathrm{mol}^{-1}$ and the second one of $1000 \mathrm{~g} \cdot \mathrm{mol}^{-1}$. The authors showed that ultrafiltration of whey protein hydrolysates resulted in mixtures of polypeptides with a slightly improved overall composition when compared to commercial whey protein concentrate: higher protein content and lower lactose and lipid content. Furthermore, mixtures of polypeptides were made up of peptides smaller than $5000 \mathrm{~g} \cdot \mathrm{mol}^{-1}$. These peptides could be applied in cosmetic products for their maximum adsorption into hair and skin and in food products for their good emulsifying properties $[3,4,10,14]$.

Several researchers studied the use of NF and UF membranes for peptide fractionation in model systems of amino acids and peptides $[6,13,18]$. Tsuru et al. [18] investigated the separation of amino acids and of small peptides (di and tri) with NF membranes. It was shown that membranes having a MWCO below $300 \mathrm{~g} \cdot \mathrm{mol}^{-1}$ were not appropriate for the separation of amino acids, while membranes with a MWCO between $2000 \mathrm{~g} \cdot \mathrm{mol}^{-1}$ and $3000 \mathrm{~g} \cdot \mathrm{mol}^{-1}$ could efficiently separate mixtures of amino acids and of peptides. The predominance of charge effects was illustrated by the impact of $\mathrm{pH}$ adjustments in the rejections of the various species by the membranes. Garem et al. [6] studied the separation of a complex mixture of 15 amino acids using two commercial membranes composed of polyamide (MWCO of $500 \mathrm{~g} \cdot \mathrm{mol}^{-1}$ ) and of cellulose polyether polyamide (MWCO of $1000 \mathrm{~g} \cdot \mathrm{mol}^{-1}$ ), both layered onto a polysulfone support. The two membranes exhib- 
ited a different behavior. The lower MWCO membranes showed high steric rejection for all the amino acids, while the separation obtained with the higher MWCO membrane was strongly dependent on the $\mathrm{pH}$, and to a lesser extent, on the ionic strength and the transmembrane pressure. The maximum selectivity was obtained at $\mathrm{pH} 10$, low ionic strength and low transmembrane pressure. Kimura and Tamano [13] used charged UF membranes for the separation of amino acids with molecular weights from 75 to $200 \mathrm{~g} \cdot \mathrm{mol}^{-1}$. The membranes were composed of sulfonated polysulfone with a charge density of $1.6 \mathrm{meq} \cdot \mathrm{g}^{-1}$ and a MWCO of $10000 \mathrm{~g} \cdot \mathrm{mol}^{-1}$. It was found that the separation of amino acids was based on differences in charges and that the rejection can be influenced by $\mathrm{pH}$ adjustment.

This section illustrates that the separation mechanism of NF and charged UF membranes is based on a molecular sieve effect and/or on a charge effect depending on membrane type and feed phase composition.

This paper aims to study the desalting of peptide mixtures from tryptic hydrolysates of whey proteins with nanofiltration membranes. The ideal membrane should allow simultaneous maximum desalting of solutions and minimal losses in peptidic material. In addition, the potential of these membranes for fractionation of peptide mixtures was investigated. A first screening of membranes was carried out under sensitive fouling conditions. An hydrolysate of whey protein concentrate containing peptides, as well as minerals, fat and lactose was filtered in a dead-end membrane configuration. Desalination experiments were performed using the better membranes under cross-flow conditions with an hydrolysate of whey protein isolate containing a mixture of peptides and minerals. Furthermore, a comparison was made between the performance of the most suitable membranes in dead-end and crossflow filtration modules.

\section{MATERIALS AND METHODS}

\subsection{Preparation of the tryptic hydrolysate from whey proteins}

The hydrolysate for the dead-end filtration experiments was made from a liquid whey protein concentrate (WPC) with a protein content of $3.24 \mathrm{w} / \mathrm{v} \%$. WPC was obtained from a local cheese plant (Groupe Lactel, Chambord, Qc, Canada). For the cross-flow filtration experiments, whey protein isolate (WPI) or Bipro (Davisco Foods International Inc., Le Sueur, MN, USA) with a protein content of $94.4 \mathrm{w} / \mathrm{w} \%$ was used as substrate for hydrolysis. Five litres of a $10 \mathrm{w} / \mathrm{w} \%$ protein solution (WPC or WPI) were introduced into a bioreactor (Biogénie Inc., Quebec, Qc, Ca) equipped with an ultrafiltration (UF) loop consisting of a $0.1 \mathrm{~m}^{2}$ generated cellulose acetate spiral wound membrane element (Amicon Canada ltd, Oakville, On, Ca) and of a $20 \mathrm{~L} \cdot \mathrm{min}-1$ capacity centrifugal pump (Cole-Parmer, MA, USA). The molecular weight cut-off (MWCO) of the membrane was $10000 \mathrm{~g} \cdot \mathrm{mol}^{-1}$ for both hydrolysates. The temperature was adjusted to $40^{\circ} \mathrm{C}$ and the $\mathrm{pH}$ was raised to 8.0 using a $2 \mathrm{~mol} \cdot \mathrm{L}^{-1}$ sodium hydroxide solution. The hydrolysis reaction was initiated by adding a predissolved solution of trypsin (PTN-6.0S, Novo Nordisk, DK). This predissolved solution consisted of $9.4 \mathrm{w} / \mathrm{v} \%$ trypsin in a $0.001 \mathrm{~mol} \cdot \mathrm{L}^{-1}$ hydrochloric acid solution. The final enzyme:substrate $(\mathrm{E}: \mathrm{S})$ ratio equaled $1: 100$. The $\mathrm{pH}$ of the reaction mixture was maintained at $\mathrm{pH} 8.0$ by addition of $2.0 \mathrm{~mol} \cdot \mathrm{L}^{-1}$ sodium hydroxide and the hydrolysis was stopped at a degree of hydrolysis (DH) of $5.6 \%$, as determined by the $\mathrm{pH}$ stat technique [1]. At this DH value, the reaction mixture was immediately circulated into the UF loop operating at $2 \times 10^{5} \mathrm{~N} \cdot \mathrm{m}^{-2}$ inlet pressure. After freeze-drying, the permeate was stored in a freezer at $-20^{\circ} \mathrm{C}$. The molecular weight distribution of the peptidic components between $>5000,2000-5000$ and $<2000 \mathrm{~g} \cdot \mathrm{mol}^{-1}$ was $13.6,26.4$ and $60.0 \%$ respectively in the hydrolysate from WPC, and 4.8, 22.9 and $72.4 \%$ in that from WPI.

\subsection{Membrane materials}

Six different flat sheet thin film composite membranes were provided by Osmonics (Minnetonka, MN, USA). Table I shows the performance characteristics of the membranes under study. Membranes of group A and B consisted of 
Table I. Characteristics of the membranes. The type of material, the advised transmembrane pressure $\left(\mathrm{P}_{\mathrm{m}}\right)$ and the molecular weight cut-off (MWCO) are given.

Tableau I. Caractéristiques des différentes membranes de nanofiltration étudiées.

\begin{tabular}{lllrc}
\hline Group & Code & Material & $\begin{array}{c}\mathrm{P}_{\mathrm{m}} \\
\left(10^{5} \mathrm{~N} \cdot \mathrm{m}^{-2}\right)\end{array}$ & $\begin{array}{c}\mathrm{MWCO} \\
\left(\mathrm{g} \cdot \mathrm{mol}^{-1}\right)\end{array}$ \\
\hline A1 & MW15 & Neg, Charg. & 6.9 & 2500 \\
A2 & MG17 & Neg, Charg. & 10.3 & 2000 \\
B1 & BQ01 & Neg, Charg. & 6.9 & 1500 \\
B2 & B006 & Neg, Charg. & 6.9 & 750 \\
B3 & B007 & Neg, Charg. & 17.2 & 400 \\
C & MX07 & Polyamide & 6.9 & 300 \\
\hline
\end{tabular}

Neg, Charg.: negatively charged/ chargé négativement.

a strongly negatively charged material layered onto a polysulfone support, whereas a polyamide layer was found on the same supporting material for the $\mathrm{C}$ membranes. The membranes were soaked overnight in $18 \mathrm{M} \Omega$ purified water (Modulab Analytical, Fischer Scientific, Montreal, Qc, Canada). The membrane area was $1.89 \times 10^{-3} \mathrm{~m}^{2}$ for the dead-end filtration experiments and $1.55 \times 10^{-2} \mathrm{~m}^{2}$ for the cross-flow filtration experiments. Every permeation experiment was performed in triplicate using different membranes.

\subsection{Permeation experiments}

Before the membrane experiments, a feed phase was prepared by redissolving the freezedried hydrolysate in purified water. The protein concentration was $0.5 \mathrm{w} / \mathrm{v} \%$. Sodium chloride (Baker analyzed, J.T. Baker Inc., Philipsburg, PA, USA) was added until a concentration of $0.5 \mathrm{~mol} \cdot \mathrm{L}^{-1}$ and the $\mathrm{pH}$ was adjusted to $7.0 \mathrm{using}$ a $0.5 \mathrm{~mol} \cdot \mathrm{L}^{-1}$ hydrochloric acid solution (ACS Assurance 36.5-38.0\%, BDH Inc, Toronto, CA).

For the dead-end filtration experiments an initial aliquot of $75 \mathrm{~mL}$ of the reconstituted hydrolysate was introduced into a Sepa ST cell (Osmonics, Minnetonka, MN, USA). Filtrations were performed at $40^{\circ} \mathrm{C}$ and under constant stirring, until $50 \mathrm{~mL}$ of permeate was collected. The volume concentration factor VCF, defined as the initial feed volume divided by the retentate volume, equaled 3 . Permeation rates were determined at $\mathrm{t}=0$ and before the concentration was completed, by measuring the volume of permeate collected after each minute.
The cross-flow filtration experiments were performed in a SEPA CF cell (Osmonics, Minnetonka, MN, USA). The temperature of the module and phases was $40^{\circ} \mathrm{C}$. The flow velocity of the feed phase was $0.33 \mathrm{~m} \cdot \mathrm{s}^{-1}$. The procedure of the experiments was the following:

Determination of the pure water flux $\mathrm{J}_{\mathrm{w}}$. Purified water $(2 \mathrm{~L})$ was circulated for $20 \mathrm{~min}$. Flux was determined from the volume of the permeate collected in $5 \mathrm{~min}$. Permeate volumes were measured during the $10-15 \mathrm{~min}$ and $15-20 \mathrm{~min}$ intervals.

Permeation of $2 \mathrm{~L}$ hydrolysate for $45 \mathrm{~min}$. Permeate volume was measured at $5 \mathrm{~min}$ intervals for calculation of the hydrolysate flux $\mathrm{J}_{\mathrm{f}}$ Since some water remains in the permeation cell, $20 \mathrm{~mL}$ of retentate was collected after one minute permeation and used as initial hydrolysate solution. The final permeate and retentate were also collected for analysis.

Rinsing with distilled water for $15 \mathrm{~min}$.

Determination of water flux $\mathrm{J}_{w}$ as described in step 1 , after a $10 \mathrm{~min}$ interval, in order to allow the flux to stabilize.

Cleaning the membrane according to a method developed by Garem et al. [6]:

- circulation of an $0.01 \mathrm{~mol} \cdot \mathrm{L}^{-1}$ sodium hydroxide solution ( $\mathrm{pH} \mathrm{12)}$ for $30 \mathrm{~min}$;

- rinsing with distilled water for 30 min until $\mathrm{pH} 7$;

- circulation of a $0.01 \mathrm{~mol} \cdot \mathrm{L}^{-1}$ salpetric acid solution ( $\mathrm{pH} 2$ ) for $30 \mathrm{~min}$;

- rinsing with distilled water for $30 \mathrm{~min}$ until $\mathrm{pH} 7$.

Determination of water flux $\mathrm{J}_{\mathrm{w}}$ as described in step 1 . 
The flux through a membrane was calculated with equation [1]:

$$
\mathbf{J}=\frac{1}{\mathrm{~A}_{\mathrm{m}}} \frac{\mathrm{dV}}{\mathrm{dt}}
$$

where $A_{m}$ is the membrane area $\left(\mathrm{m}^{2}\right)$, and $\mathrm{dV} / \mathrm{dt}$ the volume permeate $\mathrm{dV}$ collected in time $\mathrm{dt}$ $\left(\mathrm{m}^{3} \cdot \mathrm{s}^{-1}\right)$. In pressure driven membrane filtration, the solvent transport through the membrane can be described by the 'resistance in series' equation:

$$
\mathrm{J}=\frac{\mathrm{P}_{\mathrm{m}}-\sigma \Delta \pi}{\eta \mathrm{R}_{\mathrm{tot}}}
$$

where $\mathrm{P}_{\mathrm{m} \text { is }}$ the transmembrane pressure $\left(\mathrm{N} \cdot \mathrm{m}^{-2}\right)$, $\sigma$ the rejection coefficient of the membrane towards a particular solute with $0 \leq \sigma \leq 1, \Delta \pi$ the osmotic pressure difference across the membrane $\left(\mathrm{N} \cdot \mathrm{m}^{-2}\right), \eta$ the dynamic viscosity of the permeating solution $\left(\mathrm{kg} \cdot \mathrm{m}^{-1} \cdot \mathrm{s}^{-1}\right)$ and $R_{\text {tot }}$ the total resistance $\left(\mathrm{m}^{-1}\right) \cdot \mathrm{R}_{\mathrm{tot}}$ is the sum of the membrane resistance $\mathrm{R}_{\mathrm{m}}$ (determined from water flux) and additional resistances $R_{a}$ (determined from flux values with the feed material). This latter parameter contains the contribution of concentration polarization, gel layer formation and fouling [16].

The transmission of solutes ( $T$ ) was calculated concentration ratios according to the equation:

$$
\mathrm{T}_{\mathrm{i}}=\mathrm{C}_{\mathrm{Pi}} / \mathrm{C}_{\mathrm{Ri}}
$$

where subscripts $\mathrm{P}$ and $\mathrm{R}$ refer to permeate and retentate respectively.

\subsection{Analytical methods}

Analyses were performed on the hydrolysate, permeate and retentate. Total nitrogen content of the samples was determined by the Kjeldahl method [7] using a Büchi block digestor 430 equipped with a distillation unit 321 (Brinkman Instruments, Montreal, Qc, Ca).

For the dead-end experiments, sodium contents were determined by atomic absorption spectroscopy using a Model 1L751 spectrophotometer (Instrumentation Laboratory Spectrophotometers, Wilmington, MA, USA), and chloride contents were directly measured with a chloride meter (Jenway Products, Princetown, NJ, USA). Capillary electrophoresis (model ${ }^{3 \mathrm{D}} \mathrm{CE}$, Hewlett Packard, Kirkland, Qc, Canada) has been used for the determination of sodium and chloride contents in the permeates and retentates obtained from the cross-flow experiments. A silica capillary was used with an inner diameter of $50 \mu \mathrm{m}$ and a length of $72 \mathrm{~cm}$. For the analysis of anions a buffer of pyromellitic acid, sodium hydroxide, hexamethonium hydroxide and triethanolamine was used (Dionex, Sunnyvale, CA, USA). The buffer for cation analysis contained sulphuric acid, 18-crown and formic acid. The samples were injected during 4 seconds at $50 \mathrm{mbar}$. Detection wavelengths of $350 \mathrm{~nm}$ and $340 \mathrm{~nm}$ were used for anions and cations respectively.

All high performance liquid chromatography (HPLC) analyses were performed using a system consisting of an injector (Rheodyne Model 7725i, Cotati, CA, USA), a pump (Waters Model $600 \mathrm{E}$, Milford, MA, USA) and a Waters $486 \mathrm{UV}$ detector. Data were collected and treated using the chromatographic software Millennium (Waters).

For size-exclusion chromatography analysis (HPSEC), the total hydrolysate was applied to a BioSEP-SEC S2 000 column (7.8 i.d $\times 300 \mathrm{~mm}$, Phenomenex, Torrance, CA, USA) connected in series with a guard column (7.8 i.d. $\times 75 \mathrm{~mm}$ ) containing the same material. Elution was performed isocratically at $1.0 \mathrm{~mL} \cdot \mathrm{min}^{-1}$ using a solution of $0.1 \mathrm{~mol} \cdot \mathrm{L}^{-1}$ sodium phosphate, $\mathrm{pH}$ 6.8. Detection was at $220 \mathrm{~nm}$.

Reverse phase high performance liquid chromatography (RP-HPLC) analyses of the fractions were performed on a Nova-Pak $\mathrm{C}_{18} \mathrm{col}-$ umn (3.9 i.d. $\times 150 \mathrm{~mm}$, Waters, Milford, MA, USA) using the following conditions: flow rate, $1 \mathrm{~mL} \cdot \mathrm{min}^{-1}$; column temperature, $40^{\circ} \mathrm{C}$; solvent A, $0.11 \%(\mathrm{v} / \mathrm{v})$ trifluoroacetic acid (TFA) in water; solvent B, $60 \%(\mathrm{v} / \mathrm{v})$ acetonitrile and $40 \%(\mathrm{v} / \mathrm{v})$ water and $0.1 \%(\mathrm{v} / \mathrm{v})$ TFA. Samples were eluted with a linear gradient from 0 to $60 \%$ of solvent B in 30 minutes. Absorbance was measured at $220 \mathrm{~nm}$. Collected fractions were dried in a Speed-Vac concentrator (Savant Instruments, Farmingdale, NY, USA) and stored for peptide identification. After acid hydrolysis under vacuum in the presence of $6 \mathrm{~mol} \cdot \mathrm{L}^{-1} \mathrm{HCl}$ for $24 \mathrm{~h}$ at $110^{\circ} \mathrm{C}$ in a Pico-Tag Station (Waters, Milford, MA, USA), amino acids were derivatized with PITC according to the method of Bidlingmeyer et al. [2], and quantified by RPHPLC on a Pico-Tag $\mathrm{C}_{18}$ column (3.9 mm i.d. $\times 15 \mathrm{~cm}$; Waters, Milford, MA, USA). Dried samples were dissolved in a mixture of $95 \%$ $\mathrm{Na}_{2} \mathrm{HPO}_{4}\left(0.2 \mathrm{mmol} \cdot \mathrm{L}^{-1}, \mathrm{pH} 7.4\right)$ and $5 \%$ acetonitrile. The column was equilibrated in solvent A $\left(94 \%\right.$ of $0.14 \mathrm{~mol} \cdot \mathrm{L}^{-1} \mathrm{CH}_{3} \mathrm{COONa}$ plus $0.5 \mathrm{~mL} \mathrm{TFA} / \mathrm{L}$, and $6 \%$ acetonitrile) at $38^{\circ} \mathrm{C}$. Elution was performed according to the method of Bidlingmeyer et al. [2]. The flow rate was $1 \mathrm{~mL} \cdot \mathrm{min}^{-1}$ and the absorbance was recorded at $254 \mathrm{~nm}$. 


\section{RESULTS AND DISCUSSION}

\subsection{Dead-end filtration}

\subsubsection{Permeability of water and hydrolysate}

Table II summarizes the water fluxes $\left(\mathrm{J}_{\mathrm{w}}\right)$ and the hydrolysate fluxes $\left(\mathrm{J}_{0}, \mathrm{~J}_{\mathrm{f}}\right)$ through the different membranes. The B007 and BQ01 membranes show the highest water fluxes while B006 and MX07 provide the lowest. Similar trends were observed for the initial hydrolysate flux $\left(\mathrm{J}_{0}\right)$, but over a narrower range. There was no obvious relationship between MWCO of the membranes and fluxes. This implies that the membrane permeability depends not only on the MWCO, but also on the material properties (e.g., hydrophilicity and charge) and the membrane morphology (e.g., porosity and tortuosity). For the same reasons there is no relationship neither between the flux decline and the MWCO. The flux decline $\left(\mathrm{J}_{\mathrm{f}}\right.$ at $\mathrm{VCF}=3$ ) can be considered as a measure for the fouling tendency of the membranes. The higher the flux decline, the greater is the fouling of the membranes. Table III shows that membranes B006 and MX07,with the lowest water fluxes, have a higher flux decline, while B007 membrane is the opposite in terms of having a higher water flux and lower flux decline.

Since the different membranes under study were operating at different pressures, the flux values were converted into hydraulic resistances to account for these differences [Formula 2]. As seen in table III, membranes MX07 and B006 showed the highest $R_{m}$ values and the $\mathrm{BQ} 01$ the lowest. In terms of fouling resistance, distinctively high $\mathrm{R}_{\mathrm{a}}$ values were obtained with the B006 and B007 membranes. Despite the low flux data previously obtained with the MX07 membrane, its $R_{a}$ values were in a similar range to that of MW15, MG17 and BQ01 membranes. Fouling may be the result of many phenomena, such as pore blocking, pore narrowing, adsorption, internal fouling and cake layer formation $[5,16]$. The absence of a relationship between flux decline and additional resistance $\left(\mathrm{R}_{\mathrm{a}}\right)$ emphasises that the phenomenon of fouling is very complex.

Table II. Water fluxes $\left(\mathrm{J}_{\mathrm{w}}\right)$, hydrolysate fluxes $\left(\mathrm{J}_{0}, \mathrm{~J}_{\mathrm{f}}\right)$ and flux decline $\left(\left[\mathrm{J}_{0}-\mathrm{J}_{\mathrm{f}}\right] / \mathrm{J}_{0}\right)$ through different membranes using dead-end filtration. The deviations from the mean value are given between brackets.

Tableau II. Valeurs de perméabilité à l'eau $\left(\mathrm{J}_{\mathrm{w}}\right)$, des flux de perméation $\left(\mathrm{J}_{0}, \mathrm{~J}_{\mathrm{f}}\right)$ mesurés en cours de nanofiltration de solutions d'hydrolysats, et de baisse des flux $\left(\left[\mathrm{J}_{0}-\mathrm{J}_{\mathrm{f}}\right] / \mathrm{J}_{0}\right)$ obtenus avec les différentes membranes de nanofiltration en filtration frontale.

\begin{tabular}{lrrrc}
\hline Membrane & \multicolumn{1}{c}{$\mathrm{J}_{\mathrm{w}}$} & $\mathrm{J}_{\mathrm{f}}(\mathrm{t}=0)$ & $\mathrm{J}_{\mathrm{f}}(\mathrm{VCF}=3)$ & $\left(\mathrm{J}_{0}-\mathrm{J}_{\mathrm{f}}\right) / \mathrm{J}_{0}$ \\
\cline { 2 - 3 } & & $\left(10^{-6} \mathrm{~m}^{3} \cdot \mathrm{m}^{-2} \cdot \mathrm{s}^{-1}\right)$ & $(-)$ \\
\hline MW15 & $18.1( \pm 1.1)$ & $11.1( \pm 1.4)$ & $7.5( \pm 0.8)$ & $0.33( \pm 0.01)$ \\
MG17 & $26.1( \pm 0.6)$ & $11.7( \pm 2.8)$ & $7.8( \pm 0.8)$ & $0.33( \pm 0.07)$ \\
BQ01 & $43.6( \pm 1.4)$ & $11.7( \pm 0.6)$ & $7.5( \pm 0.0)$ & $0.36( \pm 0.03)$ \\
B006 & $13.3( \pm 0.6)$ & $3.6( \pm 0.8)$ & $2.2( \pm 0.3)$ & $0.38( \pm 0.05)$ \\
B007 & $49.4( \pm 7.8)$ & $11.4( \pm 1.1)$ & $8.9( \pm 0.8)$ & $0.22( \pm 0.00)$ \\
MX07 & $13.3( \pm 1.1)$ & $9.7( \pm 0.6)$ & $6.1( \pm 0.3)$ & $0.37( \pm 0.07)$ \\
\hline
\end{tabular}

$\mathrm{J}_{\mathrm{w}}$ : water flux measured at $40{ }^{\circ} \mathrm{C}$ at membrane's operating pressure; $\mathrm{J}_{\mathrm{f}}(\mathrm{t}=0)$ : initial flux of hydrolysate; $\mathbf{J}_{\mathrm{f}}(\mathrm{VCF}=3)$ : flux of hydrolysate at $\mathrm{VCF}=3$, end of experiment.

$J_{w}$ : flux de perméation à l'eau déterminé à $40{ }^{\circ} \mathrm{C}$ et à la pression recommandée ; $\mathbf{J}_{f}(t=0)$ : flux initial avec hydrolysat; $\mathrm{J}_{\mathrm{f}}(\mathrm{VCF}=3)$ : flux à $\mathrm{VCF}=3$, à la fin de l'essai. 
Table III. Membrane resistances $\mathrm{R}_{\mathrm{m}}$ and additional resistances $\mathrm{R}_{\mathrm{a}}$ for the different membranes in deadend filtration.

Tableau III. Valeurs de résistance membranaire $\mathrm{R}_{\mathrm{m}}$ et de résistance additionelle $\mathrm{R}_{\mathrm{a}}$ calculées à partir des flux de perméation obtenus avec les différentes membranes de nanofiltration en filtration frontale.

\begin{tabular}{lccc}
\hline Membrane & $\mathrm{R}_{\mathrm{m}}$ & $\mathrm{R}_{\mathrm{a}}(\mathrm{t}=0)$ & $\mathrm{R}_{\mathrm{a}}(\mathrm{VCF}=3)$ \\
\cline { 2 - 3 } & \multicolumn{3}{c}{$\left(10^{-13} \mathrm{~m}^{-1}\right)$} \\
\hline MW15 & 5.9 & 3.7 & 8.3 \\
MG17 & 6.1 & 7.5 & 14.3 \\
BQ01 & 2.4 & 6.6 & 11.7 \\
B006 & 7.9 & 21.3 & 39.6 \\
B007 & 5.3 & 17.9 & 24.4 \\
MX07 & 7.9 & 3.0 & 9.4 \\
\hline
\end{tabular}

\subsubsection{Permeability of salts and peptides}

The rejection properties of the membranes studied in terms of the permeation of sodium and chloride ions, and nitrogen (table IV). The transmission values were high (0.79-0.99) for $\mathrm{Na}^{+}$and $\mathrm{Cl}^{-}$, and low $(0.12-0.22)$ for $\mathrm{N}$. At $\mathrm{pH} 7$, the negative charges of the membrane surface are shielded by the monovalent counter-ions and, consequently, repulsive effects and differences in electrical potential are suppressed. A more detailed examination of the transmission data for MX07 membrane reveals the highest selectivity for sodium (8.2) and chloride (8.3), followed by the B007 membrane with selectivity values of 6.1 and 6.4. Since MX07 shows higher transmissions for $\mathrm{Na}^{+}$and $\mathrm{Cl}^{-}$than $\mathrm{B} 007$, the former membrane is more appropriate for desalination applications.

Due to $\mathrm{N}$ losses through the membranes, permeates were analyzed by RP-HPLC in order to detect and characterize the peptides present. For all membranes, a very low amount of peptides was found in the permeate between $2 \%$ w/w (MX07) and $11 \%$ w/w (MW15). Also, a similar pattern of 5 to 6 peaks was found in all the chromatograms. The permeate from the lowest MWCO membrane MX07 showed the lowest amount of peptides: 6 different peptide sequences of $\beta$-lactoglobulin $(\beta-\mathrm{lg})$ were found. Peptides listed in table $V$ were all present in permeates from MW15, MG17 and BQ01 membranes, whereas only the $\beta$ - $\lg 1-8$ and $\beta$ - $\lg 136-138$ peptides were found in the permeate from membrane MX07. As seen in table VI, the peptides identified in the permeate were characterized by molecular weight (MW) values in a range from $312 \mathrm{~g} \cdot \mathrm{mol}^{-1}$ (B-lg 139-141) to $933 \mathrm{~g} \cdot \mathrm{mol}^{-1}(\beta-\lg 1-8)$, average hydrophobicity between $1340 \mathrm{cal} / \mathrm{res}(\beta-\lg 1-8)$ and $2030 \mathrm{cal} / \mathrm{res}(\beta-\lg 136-138)$ and net charge values of 0 or +1 . It may be hypothesized that, because of increased ionic strength, repulsive effects due to the negatively charged membrane are suppressed, and therefore, the transmission of peptides is dictated by steric exclusion. The peptide distribution in the permeates from the B series (BQ01, B006, B007) partly supports this idea. Different peptide profiles were obtained in permeates from membranes of the same material but with decreasing MWCO. Whereas BQ01 (1500 g.mol $\left.{ }^{-1}\right)$ permeate contained all the 6 peptide species, B006 $\left(750 \mathrm{~g} \cdot \mathrm{mol}^{-1}\right)$ and B007 $\left(300 \mathrm{~g} \cdot \mathrm{mol}^{-1}\right)$ contained 5 and 4 peptide species respectively. Nevertheless, we also need to consider the observation that all peptides found 
Table IV. Transmission of sodium $\left(\mathrm{T}_{\mathrm{Na}}\right)$, chloride $\left(\mathrm{T}_{\mathrm{Cl}}\right)$, nitrogen $\left(\mathrm{T}_{\mathrm{N}}\right)$, and selectivity for different membranes during dead-end permeation of whey protein hydrolysates.

Tableau IV. Données de transmission du sodium $\left(\mathrm{T}_{\mathrm{Na}}\right)$, des chlorures $\left(\mathrm{T}_{\mathrm{Cl}}\right)$, de l'azote $\left(\mathrm{T}_{\mathrm{N}}\right)$, et valeurs de sélectivité calculées avec les concentrations déterminées dans les rétentats et les perméats obtenus en nanofiltration frontale.

\begin{tabular}{lccccc}
\hline Membrane & $\mathrm{T}_{\mathrm{Na}}$ & $\mathrm{T}_{\mathrm{Cl}}$ & $\mathrm{T}_{\mathrm{N}}$ & $\begin{array}{c}\text { Selectivity } \\
\left(\mathrm{T}_{\mathrm{Na}} / \mathrm{T}_{\mathrm{N}}\right)\end{array}$ & $\begin{array}{c}\text { Selectivity } \\
\left(\mathrm{T}_{\mathrm{Cl}} / \mathrm{T}_{\mathrm{N}}\right)\end{array}$ \\
\hline MW15 & 0.98 & 0.98 & 0.19 & 5.2 & 5.2 \\
MG17 & 0.98 & 0.93 & 0.19 & 5.2 & 5.0 \\
BQ01 & 0.94 & 0.94 & 0.22 & 4.3 & 4.3 \\
B006 & 0.98 & 0.96 & 0.18 & 5.4 & 5.3 \\
B007 & 0.79 & 0.83 & 0.13 & 6.1 & 6.4 \\
MX07 & 0.99 & 0.98 & 0.12 & 8.3 & 8.2 \\
\hline
\end{tabular}

Table V. Identification of $\beta$-lactoglobulin ( $\beta$-lg) peptides found in permeates using dead-end filtration. Tableau V. Identification des peptides dans les perméats obtenus en filtration frontale.

\begin{tabular}{lcccccc}
\hline Membrane & \multicolumn{7}{c}{ AA residues from $\beta$-lg } \\
\cline { 2 - 6 } & $1-8$ & $15-20$ & $78-83$ & $136-138$ & $139-141$ & $142-148$ \\
\hline MW15 & $\times$ & $\times$ & $\times$ & $\times$ & $\times$ & $\times$ \\
MG17 & $\times$ & $\times$ & $\times$ & $\times$ & $\times$ & $\times$ \\
BQ01 & $\times$ & $\times$ & $\times$ & $\times$ & $\times$ & $\times$ \\
B006 & $\times$ & $\times$ & $\times$ & & $\times$ & $\times$ \\
B007 & $\times$ & $\times$ & $\times$ & & $\times$ & $\times$ \\
MX07 & $\times$ & & & $\times$ & & \\
\hline
\end{tabular}

in the permeates had a net charge of 0 or +1 . At the same time, the retentate phases contained three peptides with a MW lower than $1000 \mathrm{~g} \cdot \mathrm{mol}^{-1}$ (table VI), which should have been present in the permeates if steric exclusion is the governing mechanism during membrane filtration. These three peptides contain at least one acidic amino acid residue (Glu or Asp) with a negative charge during the operation at $\mathrm{pH} \mathrm{7.} \mathrm{By} \mathrm{contrast,}$ the peptides found in permeates contain no acidic amino acid residue, except for $\beta$-lg $136-138$. This observation is in good agreement with Tsuru et al. [18] who observed high rejective properties of nanofiltration membranes for charged (acidic or basic) peptides.

\subsection{Cross-flow filtration}

\subsubsection{Permeability of water and hydrolysate}

For the cross-flow filtration experiments, three different types of membranes were selected out of the series used for dead-end filtration, namely the membrane with the better desalination properties (MX07) and two membranes with possible applications for peptide separation (MG17 and MW15). In table VII, the water and hydrolysate fluxes and the hydraulic resistances obtained in cross-flow filtration are presented. No relationship is observed between the MWCO of the membranes and the fluxes or resis- 


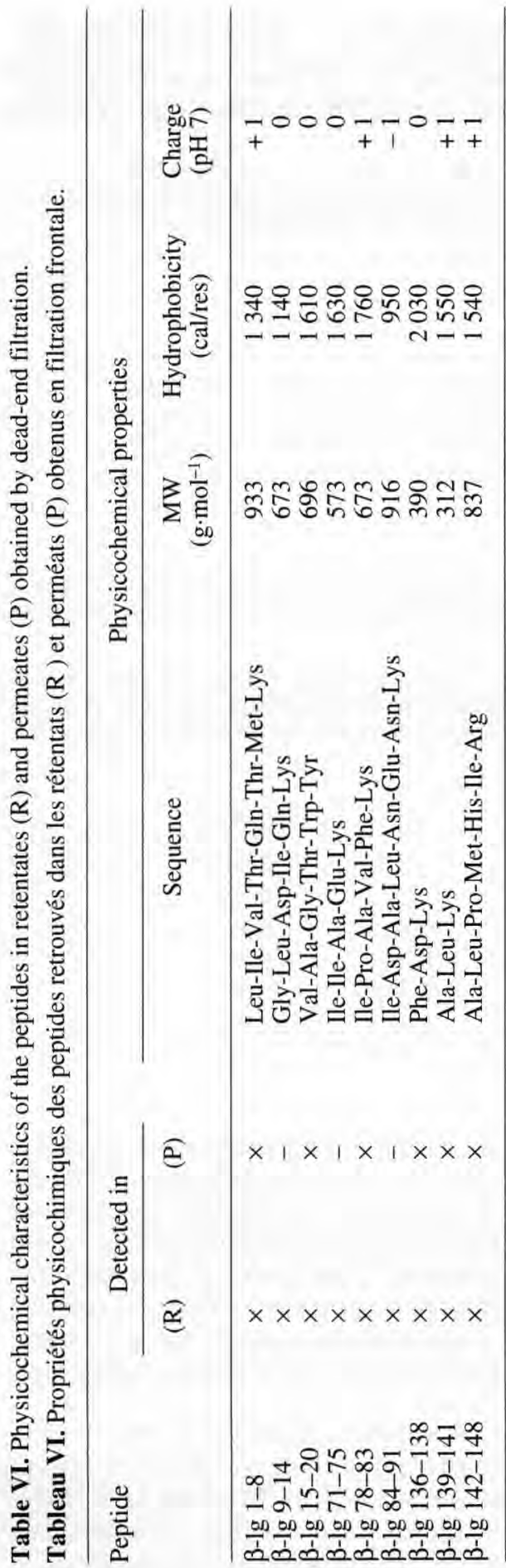

tances, when results are compared at a transmembrane pressure of $5 \times 10^{5} \mathrm{~N} \cdot \mathrm{m}^{-2}$. Likewise for the dead-end filtration experiments, this can be explained by the fact that permeability and fouling (reflected in $\mathrm{R}_{\mathrm{a}}$ ) does not only depend upon the MWCO of the membranes but also upon their material and morphology. Increasing $\mathrm{P}_{\mathrm{m}}$ by a factor of 2 results in doubling of flux the membrane MG17. This means that within this $P_{m}$ range, the solvent flux is linearly related to the transmembrane pressure according to Darcy's law [formula 2]. The hydrodynamic resistance $R_{m}$ is a membrane constant and should not be affected by feed composition or applied pressure [16]. When the deviations in membrane resistances for MG17 (table VII) are considered, the membrane resistances do not change significantly with the transmembrane pressure.

\subsubsection{Permeability of salts and peptides}

All membranes show high transmission values for $\mathrm{Na}^{+}$and $\mathrm{Cl}^{-}$, but very low values for nitrogen (table VIII). With the exception of MG17 and MX07, $\mathrm{Na}^{+}$permeation increased with increasing MWCO of the membranes. This may imply that the transport of the solutes through the membranes is based on steric exclusion. Furthermore, by increasing the transmembrane pressure over MG17 with a factor 2, the transmission of the solutes decreases slightly. This is because the solvent (water) flux through the membrane is related linearly to the pressure difference applied, whereas the solute transmission $\left(\mathrm{Na}^{+}, \mathrm{Cl}^{-}\right.$, peptides) depends upon the concentration difference over the membrane as well as solvent flux. With increasing pressure difference, flux increases of the solvent are greater than that of the solutes. This decreases permeate concentration and transmission [16, 17]. The ion and nitrogen selectivities are highest for MX07 due to their lowest transmission values for nitrogen. Permeates collected from membranes MW15 and MX07 contained the 
Table VII. Water fluxes $\mathrm{J}_{w}$ and hydrolysate fluxes $\mathrm{J}_{\mathrm{f}}$ through different membranes using cross-flow filtration. The membrane resistances $\mathrm{R}_{\mathrm{m}}$, additional resistances $\mathrm{R}_{\mathrm{a}}$ and the volume concentration factor (VCF) after 45 minutes are also shown. The deviations from the mean value in the fluxes and resistances are given between brackets. Two different transmembrane pressures $\mathrm{P}_{\mathrm{m}}$ were applied for MG17.

Tableau VII. Valeurs de perméabilité à l'eau $\left(\mathrm{J}_{\mathrm{w}}\right)$, de flux de perméation $\left(\mathrm{J}_{0}, \mathrm{~J}_{\mathrm{f}}\right)$, de baisse des flux $\left(\left[\mathrm{J}_{0}-\mathrm{J}_{\mathrm{f}}\right] / \mathrm{J}_{0}\right)$, de résistance membranaire $\mathrm{R}_{\mathrm{m}}$, de résistance additionelle $\mathrm{R}_{\mathrm{a}}$ et de facteur de concentration (VCF) obtenues avec les différentes membranes de nanofiltration en filtration tangentielle.

\begin{tabular}{|c|c|c|c|c|c|c|}
\hline Membrane & $\begin{array}{c}\mathrm{P}_{\mathrm{m}} \\
\left(10^{5} \mathrm{~N} \cdot \mathrm{m}^{-2}\right)\end{array}$ & $\begin{array}{c}\mathrm{J}_{\mathrm{w}} \\
\left(10^{-6} \mathrm{~m}^{3} \cdot \mathrm{m}^{-2} \cdot \mathrm{s}^{-1}\right)\end{array}$ & $J_{f}$ & $\begin{array}{c}\mathrm{R}_{\mathrm{m}} \\
\left(10^{13} \cdot \mathrm{m}^{-1}\right)\end{array}$ & $\mathrm{R}_{\mathrm{a}}$ & VCF \\
\hline MW15 & 5.0 & $11.8( \pm 0.5)$ & $6.6( \pm 0.3)$ & $6.5( \pm 0.3)$ & $4.6( \pm 0.1)$ & 1.2 \\
\hline MG17 & 5.0 & $5.8( \pm 0.6)$ & $3.4( \pm 0.3)$ & $13.6( \pm 1.5)$ & $7.4( \pm 0.3)$ & 1.1 \\
\hline MX07 & 5.0 & $15.3( \pm 1.6)$ & $10.6( \pm 0.9)$ & $5.1( \pm 0.5)$ & $0.5( \pm 2.5)$ & 1.3 \\
\hline MG17 & 10.0 & $13.1( \pm 1.3)$ & $6.2( \pm 0.0)$ & $9.1( \pm 3.8)$ & $8.6( \pm 2.2)$ & 1.1 \\
\hline
\end{tabular}

Table VIII. Transmission of sodium $\left(\mathrm{T}_{\mathrm{Na}}\right)$, chloride $\left(\mathrm{T}_{\mathrm{Cl}}\right)$, nitrogen $\left(\mathrm{T}_{\mathrm{N}}\right)$, and selectivity for different membranes during cross-flow permeation of whey protein hydrolysates. Two different transmembrane pressures $\mathrm{P}_{\mathrm{m}}$ were applied for MG17.

Tableau VIII. Données de transmission du sodium $\left(\mathrm{T}_{\mathrm{Na}}\right)$, des chlorures $\left(\mathrm{T}_{\mathrm{Cl}}\right)$, de l'azote $\left(\mathrm{T}_{\mathrm{N}}\right)$, et valeurs de sélectivité calculées avec les concentrations déterminées dans les rétentats et les perméats obtenus en nanofiltration tangentielle. Deux pressions transmembranaires étaient utilisées pour la membrane MG17.

\begin{tabular}{lcccccc}
\hline Membrane & $\begin{array}{c}\mathrm{P}_{\mathrm{m}} \\
\left(10^{5} \mathrm{~N} \cdot \mathrm{m}^{-2}\right)\end{array}$ & $\mathrm{T}_{\mathrm{Na}}$ & $\mathrm{T}_{\mathrm{Cl}}$ & $\mathrm{T}_{\mathrm{N}}$ & $\begin{array}{r}\text { Selectivity } \\
\left(\mathrm{T}_{\mathrm{Na}} / \mathrm{T}_{\mathrm{N}}\right)\end{array}$ & $\begin{array}{r}\text { Selectivity } \\
\left(\mathrm{T}_{\mathrm{Cl}} / \mathrm{T}_{\mathrm{N}}\right)\end{array}$ \\
\hline MW15 & 5.0 & 1.07 & 1.08 & 0.12 & 8.9 & 9.0 \\
MG17 & 5.0 & 0.84 & 0.88 & 0.09 & 9.3 & 9.8 \\
MX07 & 5.0 & 0.89 & 0.84 & 0.04 & 22.3 & 21.0 \\
MG17 & 10.0 & 0.82 & 0.83 & 0.07 & 11.7 & 11.9 \\
\hline
\end{tabular}

highest $(7 \%)$ and lowest $(2 \%)$ content of peptides respectively.

\subsection{Comparison of dead-end and cross-flow filtration}

The design of membrane filtration systems depends on the application and module configuration. A simple design is dead-end operation where all the feed is forced through the membrane. This implies that the concentration of rejected components in the feed phase increases and consequently the quantity of the permeate decreases in time. For industrial applications, a crossflow operation is preferred because of lower fouling tendency and better fouling control compared to the dead-end module. In the cross-flow operation, the feed flows parallel to the membrane surface and is separated into a permeate and a retentate stream [16].

A successful desalting of whey protein tryptic hydrolysates was obtained with all the membranes studied, both in dead-end filtration and cross-flow filtration. The MX07 was the most suitable for desalting 
because of the higher selectivity of the membranes tested, lower hydraulic resistances and satisfactory flux values. Salt removal was $86-89 \%$ for dead-end and $28-31 \%$ for cross-flow filtration. This does not implicitly mean that dead-end filtration is a better design than cross-flow filtration. In crossflow filtration experiments, the permeation of the hydrolysate was completed at a volume concentration factor of 1.3 (i.e., an operation time of $45 \mathrm{~min}$ ), whereas in the dead-end filtration experiments the hydrolysate permeation was carried out until a VCF of 3 . Thus, $23 \%$ of the initial feed volume permeated through the membrane using cross-flow filtration compared to $67 \%$ using dead-end filtration. In addition, the selectivities obtained were considerably higher, namely a factor of $2.6-2.7$, for filtration under cross-flow.

Furthermore, these results showed that the membranes can not only be applied for desalination purposes but also for separation of peptidic material. The mechanism of transmission of peptides has not been fully elucidated yet, but both size and charge effects play a role. Comparing the transmission values for nitrogen $\mathrm{N}$ with the MWCO of the membranes, the size exclusion effect seems to be more important for cross-flow than dead-end filtration. Characterization of the peptidic material in retentate and permeate phases for the dead-end experiments suggests that peptide separation is also governed by charge effects.

In a comparison between cross-flow and dead-end experiments (tables II, III and VII), fluxes for MW15 and MC17 are lower for cross-flow filtration. The fluxes through the NF membrane MX07 are similar for both filtration designs. All membrane resistances are higher for cross-flow permeation. No fundamental difference can be observed when comparing the additional resistances of the two designs. Our results support the comparison obtained from literature, which has been made between dead-end and crossflow filtration in the beginning of this sec- tion. The recovery, or, fluxes are higher in the dead-end system. Secondly, fouling phenomena predominate in the dead-end system. In cross-flow experiments, the hydrolysate flux did not change significantly during the permeation time, whereas in the dead-end filtration experiments these fluxes decreased. Fouling occurred also in the cross-flow experiments, but its effect on flux was negligibly small for over a $45 \mathrm{~min}$ operating period.

However, when comparing the permeation results of cross-flow and dead-end experiments care has to be taken, because of:

Differences in feed phases. The hydrolysates of WPI and of WPC differ in composition because of the respective differences in the starting materials.

Differences in hydrodynamic conditions affecting mass transport through the membrane, concentration polarization and fouling mechanisms.

The latter argument is especially critical in the light of recent work from Garem et al. [4] who have presented data which evidence the governing role of charged solutes and macromolecules in the concentration polarization (CP) layer during NF of casein peptide solutions. It is therefore difficult to compare the selectivity of dead-end and cross-flow filtration systems since there was obviously not the same control on the $\mathrm{CP}$ formation.

\section{CONCLUSION}

This paper demonstrated the potential of charged membranes for desalting of peptidic solutions. A polyamide membrane with the lowest MWCO (MX07) was the most suitable for this purpose, mainly because of its higher peptide rejection properties.

The best fractionation of peptides was obtained with the highest MWCO membranes MW15 and MG17. Our work to optimize the fractionation of peptides and to 
better understand the mechanism of transmission through charged membranes will be continued.

A comparison between dead-end and cross-flow filtration revealed that the latter is preferable in overall performance terms. Despite the lower fluxes in cross-flow filtration, higher ion-peptide selectivities and less fouling were found compared to the dead-end filtration design.

\section{ACKNOWLEDGMENTS}

The authors wish to thank Steeve Harrold, from Osmonics (Minnetonka, MN, USA), for providing membrane materials and for his advice in establishing the experimental set-up. This work was supported by a grant from the Natural Sciences and Engineering Research Council of Canada (NSERC).

\section{REFERENCES}

[1] Adler-Nissen J., Enzymic hydrolysis of food proteins, Process Biochem. 12 (1977) 18-24.

[2] Bidlingmeyer B.A., Coehn S.A., Tarvin T.L., Rapid analysis of amino acids using precolumn derivatization, J. Chromatogr. 336 (1984) 93-104.

[3] Chobert J.M., Bertrand-Harb C., Nicolas M.G., Solubility and emulsifying properties of caseins and whey proteins modified enzymatically by trypsin, J. Agric. Food Chem. 36 (1988) 883-892.

[4] Garem A., Daufin G., Maubois J.L., Chaufer B., Léonil J., Ionic interactions in nanofiltration of $\beta$-casein peptides, Biotechnol. Bioeng. 57 (1998) 109-117.

[5] Garem A., Jeantet R., Fouling occuring in nanofiltration of dairy products, Special issue: Fouling and cleaning in pressure driven membrane processes, Bull. Int. Dairy Fed. 9504 (1995) 71-79.

[6] Garem A., Léonil J., Daufin G., Maubois J.L., Nanofiltration d'acides aminés sur membranes organiques: influence des paramètres physico- chimiques et de la pression transmembranaire sur la sélectivité, Lait 76 (1996) 267-281.

[7] IDF Provisional Standard 20A, International Dairy Federation, Brussels, Belgium, 1986.

[8] Jeantet R., Schuck P., Famelart M.H., Maubois J.L., Intérêt de la nanofiltration dans la production de poudres de lactosérum déminéralisées, Lait 76 (1996) 283-301.

[9] Jelen P., Nanofiltration - A new membrane processing application for demineralization in the dairy industry, Can. Inst. J. Food Sci. Technol. 24 (1991) 200-202.

[10] Johnson V.L., Proteins in cosmetic and toiletries, Drug. Cosmet. Ind. 126 (1980) 136-138.

[11] Kelly J., Kelly P., Nanofiltration of whey: quality, environmental and economic aspect, J. Soc. Dairy Technol. 48 (1995) 20-25.

[12] Kelly J., Kelly P., Desalination of acid casein whey by nanofiltration, Int. Dairy J. 5 (1995) 291-303.

[13] Kimura S., Tamano A., Separation of aminoacids by charged ultrafiltration membranes. Membranes and membrane processes, in: Drioli E., Nahagaki M. (Eds) Plenum Press, New York, 1986, pp.191-197.

[14] Lee S.W., Shimizu M., Kaminogawa S, $_{+}$ Yamauchi K., Emulsifying properties of peptides obtained from the hydrolyzates of $\beta$-casein, Agric. Biol. Chem. 51 (1987) 161-166.

[15] Marshall W.E., Amino acids, peptides and proteins. Functional Foods, Designer Foods, Pharmafoods, Nutraceuticals, in: Goldberg I. (Ed.) Chapmann and Hall, N Y, 1994, pp. 242-260.

[16] Mulder M., Basic principles of membrane technology, Second edition, Kluwer Academic Publishers, Dordrecht, The Netherlands, 1996.

[17] Peeters J.M.M., Characterization of nanofiltration membranes. Dissertation, University of Twente, The Netherlands, 1997.

[18] Tsuru T., Shutou T., Nakao S.I., Kimura S., Peptide and amino acid separation with nanofiltration membranes, Separ. Sci. Technol. 29 (1994) 971-984.

[19] Turgeon S.L., Gauthier S.F., Whey peptide fractions obtained with a two-step ultrafiltration process: production and characterization, J. Food Sci. 55 (1990) 106-110 and 157.

[20] Van der Horst H.C., Timmer J.M.K., Robbertsen T., Leenders J., Use of nanofiltration for concentration and demineralization in the dairy industry: Model for mass transport, J. Membrane Sci. 104 (1995) 205-218. 